\title{
製品紹介 新規の万能型屈曲摩粍試験機
}

福井大学工学部 斉藤、楢夫

最近新しく作られた甚だ便利且つ有効な瀻維及び糸布 の試験機を紹介する. 第 1 図写真は新試作の本機第 2 号 型である。

本機の主目的は瀻雉, 系篠及び織物の届曲摩䉿性を測 定検査するにあるが, 染色の摩擦筀牢度, 洗濯堅牢度及 び静電発生, 摩擦熱等をす測定できる. 又特殊なるのは 引银試験も可能である.

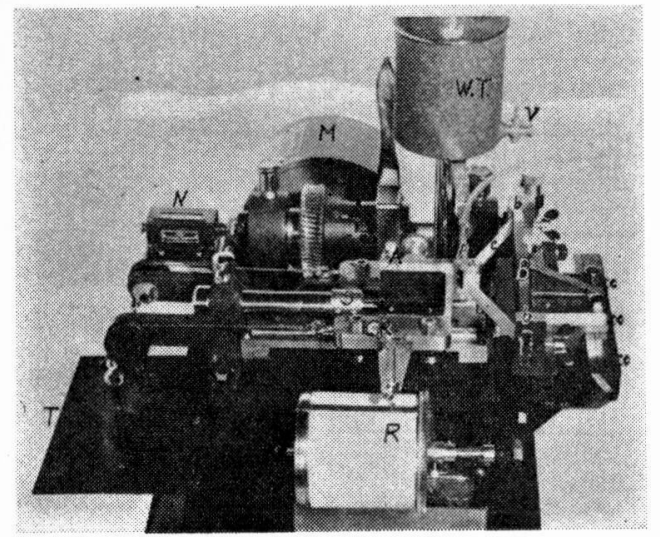

（第1図）万能型屈曲摩耗試験機

その禨構と特長とについて述べると, 写真中の $A a$ が 取りはずし可能である. $\boldsymbol{a}$ が屈曲摩粍部分で, $A$ の一つ の先端に当る.この部分にピアノ線が V字の三つの頂点 に当る所に 3 本垂直に植込まれて山る. 布 $c$ は $b, b$ で 支えられ, $A a$ と直角に往復運動する $b B b$ のために $a$ 点で $M$ 形となって, ピアノ線に対して一定の張力 $T$ の下でしごかれる訳である. 従って布 $c$ は短時間の間 に $\vec{\wedge} \wedge$ と往復屈曲して, 中でも中央が疲労最も大で あるため中央で切断する. その往復回数を回転計 $N$ で 読みとる， $R$ は記錄装置で回数と伸びとがよめる． $M$ はモータ, $W T$ は水又は溶液のタンクである. 水, 洗 潅液その他を満たし, 弁 $V$ とパイプ $p$ とによって測定 中布 $c$ を常に妨すことも出来る. 布 $c$ が切れると, $A$ を支光た e rriadge $C R$ が, 図の左方の方に動き, $S$ の 一部に触れると電源を自動的に切って $M$ は止まる.こ のよろにして「に扔いて荷重を種々に变えて，乞れぞ れの荷重に対する $N$ を測定する。

袎構上の特長は, $a$ 部における針金の種々異なったも のを用意して拓き簡単に $A a$ を変えることによって，本 機1 台で単瀻維, 系及び織物等, とれも甚だ薄いものか ら厚手のものに至るまで測定できる. 又 $A a$ の特殊なる のを用いると染色の摩擦堅牢度が, 乾燥状態でも湿溜状

態でも測定できる. 従ってパイル織物の耐摩粍性, 染色 の汗等による摩擦堅牢度試験も容易である. 耐洗濯性も 試験できるわけである.

$$
\text { （第 } 1 \text { 表） }
$$

本機と各種試験機とのスフモスとよる变動率の比較

\begin{tabular}{l|r|r|r|r|r}
\hline \hline 試 験 機 & 荷 重 & 試験数 測定回数 $\mid$ 標準偏差 & 変動率 \\
\hline ショッパ型 & $1000 \mathrm{~g}$ & 10 & 6425 & \pm 796 & 12.4 \\
アムスラ型 & $2000 \mathrm{~g}$ & 10 & 12034 & \pm 2500 & 20.8 \\
$\mathrm{U}$ M 型 & $800 \mathrm{~g}$ & 80 & 463 & \pm 42.1 & 9.1 \\
本 試 験 機 & $900 \mathrm{~g}$ & 6 & 1189 & \pm 81.4 & 6.9 \\
\hline
\end{tabular}

又特別な附属装置によって靜電発生や摩擦発熱も測定 できるといろ利点がある・な颃目下設計中のものでは 引張試験も行い得るようになっている.

头に測定上の特長はといらと,これは従来の摩耗試験 機よりも測定結果の变動率は割合に小さい.(第1表参照) 又従来知られている Stoll Quatprmaster Tester に比

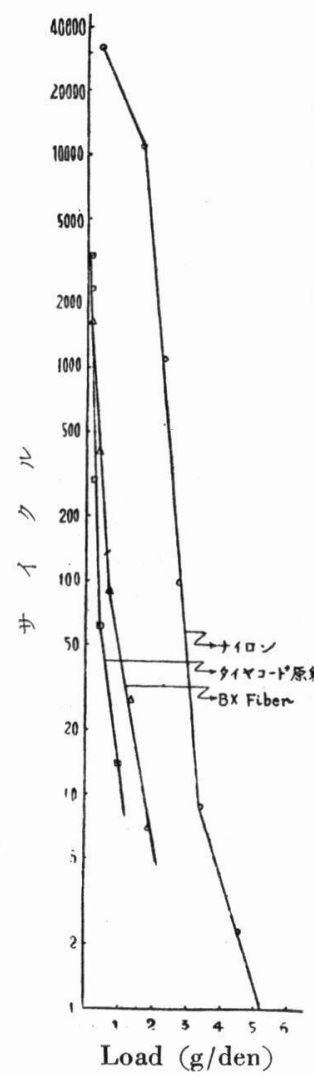

（第2 図）各種纎維の種 々の初荷重之屈曲摩耗切 断数との関係
しより完全な屈曲状態で試験 するわけである・従って従来不 明確であった耐屈曲性だとか耐 久性に当る性質がより良く明ら かにされることが特長である。 な颃各種の荷重の下で得た切 断志での往復回数 $N$ の対数を とって荷重に対して plotする と, 各自の試料の特長に応じて

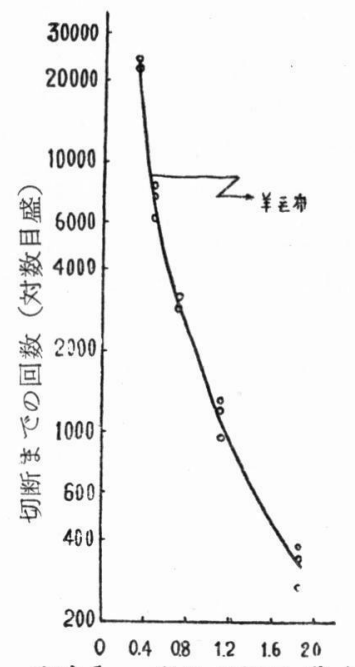
布巾 $1 \mathrm{~cm}$ 当りの荷重 $(\mathrm{kg})$ (第3 図) 羊毛厚手布の Cycle-Load 特有曲線 


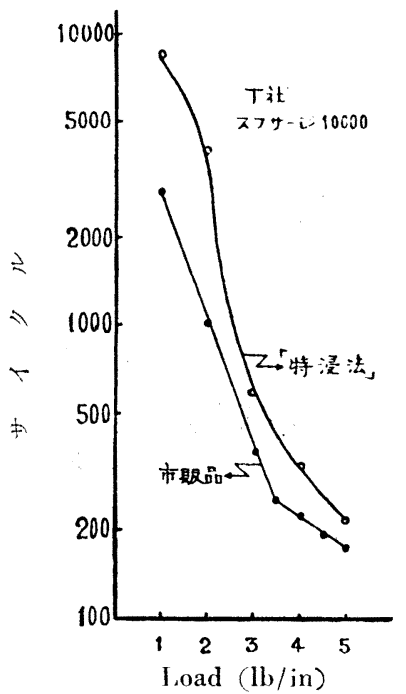

(第 4 図) スフサージの同一布で の「特浸法」加工之市販加工との Cycle-Load 特有曲線の比較
それぞれ独自の特質 曲線が得られる。市 るもの性つかの值 線の集りとなる。

(第 $2 \sim 6$ 図参照)

これは甚しく興味 と奏益のあるもので ある・なぜにこのよ らになるかといらと 大体次の如く説明与 ることができる・即 らこの試騃中試料に 与亲る效果は各種の 複稚な Stress 学含 んでいる・例えば

Bending, Shearing,

Tortional, Tensile,

Compressive, Stress

等或はとれ等のどれかの複合したるのが働く. 彷ってこ のものが試料に及佸す綜合的効果は, 試料兒身の纎維の 特泩, 即ち分子の構造, 長短, 配列上の組織構造, 或は 瀻維の集合からなる系の成立条件，又は系の集合によっ てなる織物の物理的乃至幾何学的要素等の差異, 特長等 に徉ってそれそれれ相違してくるはずである・剘ら試料に とっては收ぼされた效棵の受入れすがこれぞれ一様では なく，隹ってえの場合傷み方がそれぞれ異なるふらに表

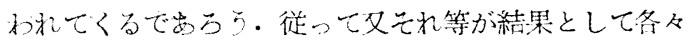

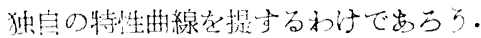

例灾ば・イロン 釆吼て双る上 第2図の如く明ら 小心 次直線部 分比分れた。これ はそれぞれの直線 部分では，切断心 至る傷方がえれ それれ別及な機構に 基いていることを 示している・織物 の場合は，羊毛元 り他法いて（第 3 図)曲線になる つがあるが，公机 でも特殊のあので 壮第4図の下の如 く明確な百線部分 坐じたものが女 る.これも酠料の

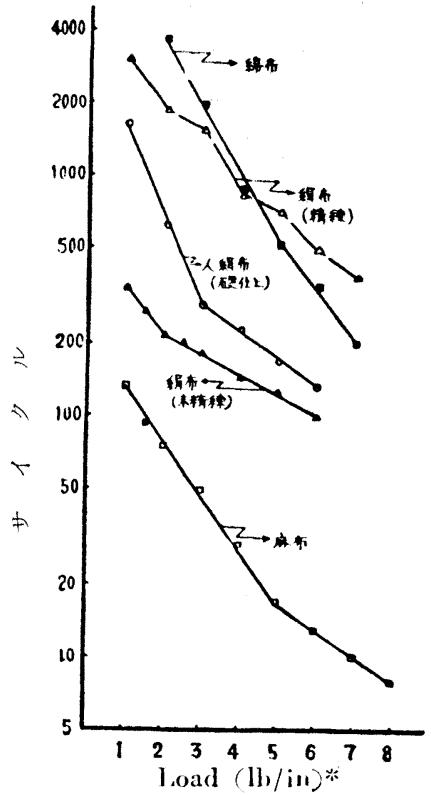

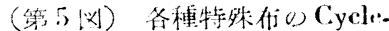
load 名ラフ山明明な $K$ 占 价発現走示与

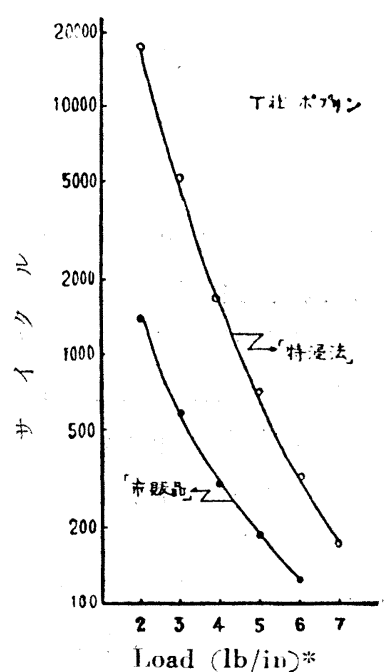

*仿巾 1 in 当りに換算し花闩重 （第6困） ポプリン布での

「特浸法」加工之市板加工 との比較

性質と関連があって特 長的である・この場合 もとれぞれの直線部分 では，切断化至るまで の試料の傷み方がそれ ぞれ異なることを示し ている。このように直 線部に Knick point ができるものでは纎維 の配列が良すぎて伸度 の少いものか，何かが くっついて外硬的にな っているるのか, 又織 物としてもこのような 䕙維でできたものか， 或は何か硬いものが膠 着しているか等の持に

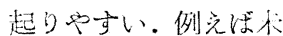
精練の生絹の織物, 䏫有, 硬认のり付存, 外部樹脂加下: の硬仕上の布或は樹脂加工による纎維の改質がイ゚分で 外硬的になっているようなる。等の場合に袁わ机る(啭 5 目渗照)

往って外钼だけでは一间分らない外硬的な外部或程䋐

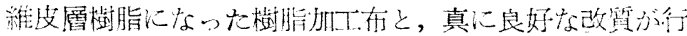
われている芯部樹脂加工の製品とはこの僟械によ。て弁 別することができる・（第4図参照）こして上手に加工 すると同じ生地を使っても 3 〜 部耐久性の向上が其待 できる（第4四参照）又少し手をかけると13倍も向上

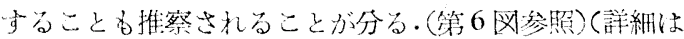
帝人夕イム六誌，第 275 号炤和30年. 6 月号参照)

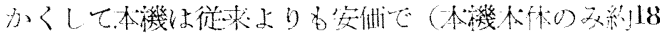

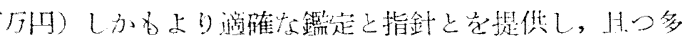

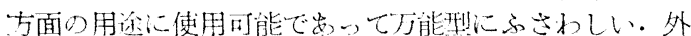

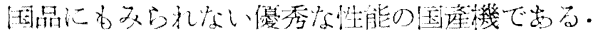

今本機の使用分野定推定してみると

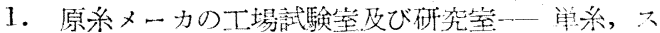
フ系攻びタイヤコード效びその原系，織物等の試験

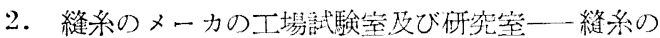
盖曲性と擘擦性の試験

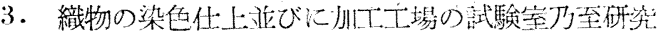

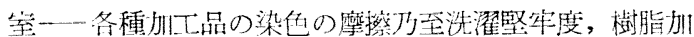

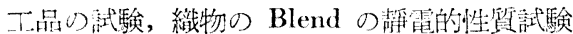

4. 特殊織物，パイル織物の工場試験空，研究荠- ハイイル織物,モケットの摩耗試騒,染色の塈擦堅牢度試験

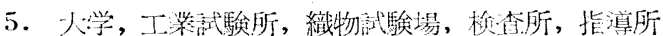

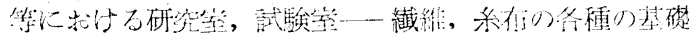

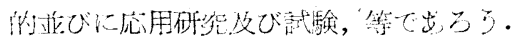

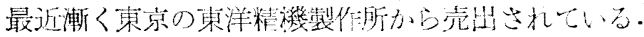




\section{最近のオートタイマについて}

\section{概 說}

常時時計を睨みながら人間が作業をせねばならぬよう な, 人間が機械に使われた時代は過去のすので, 合理化 の進んだ能率時代の現在では，それぞれの目的に合った 精巧なオートタイマを用いて,人間以上の正確さと勤勉 さで，機械を自由自在に駆使し，人間は機械を監督する だけで，作業管理と品質管理の実を挙げる時代である. 以下オート タイマの概要を述べるとととする.

本器は時間を計数し, 內燃する電気接点を開閉動作し 自動制御装置に関連させるめので, 計時要素には, 電子 管式, 同期モートル式, 発条式の 3 種があり, 短時間の ものは, 電子管をそれ以外のものは, 同期モートルを用 いている. 発条式は, 直流電源による制御, 停電しても 続けてする制御等に用いられ, 発条式は短時間のものは 動作時に電磁石で附勢するが, 主として內燃する小型モ ートルで発条を参込み蓄勢し, 常に駆動力を保有するよ ろにしたものを用いている。

\section{特長}

1）調整ダイヤルと動作指針があり，動作指針はセッ ト点から 0 に向って進むようになっているから, 常に予 定值と動作過程が直読できる.この種のタイマで, セッ 卜時間と経過時間を同時に表示するすのは, 弊社製品を もって矯矢とするものである.

2）微調整ダイヤル付のものもあって, 精密調整がで きる・

3) 自動復帰繰返運転, 遠方自動復帰等も可能である 故, 他の自動制御装置と組合せ, 無人繰返制御ができ る.

4) 任意時間の繰返し, 又は正逆反覆運転も可能であ る.

5) 本器は簡単な㢄夜電灯の切換えから, 化学反応の 時間等制御を始め, 長時間の多重継続制御中に, 短時精 密時間をる重復せるシーケンス制御等の複雑な制御も極 めて簡単にできる。

次に例を挙げて說明する。

\section{ATM一C 型週期タイマ（第 1 図参照）}

㡺夜電灯の自動点隇の如く, $24 \mathrm{hr}$ 中可変調整の特定 時限內のみ動作し, 毎日週期的に繰返し, 動作する の に用いられ, 動作前後に短時間動作する. 接点を挿入し 警報等に用ろることもできる。

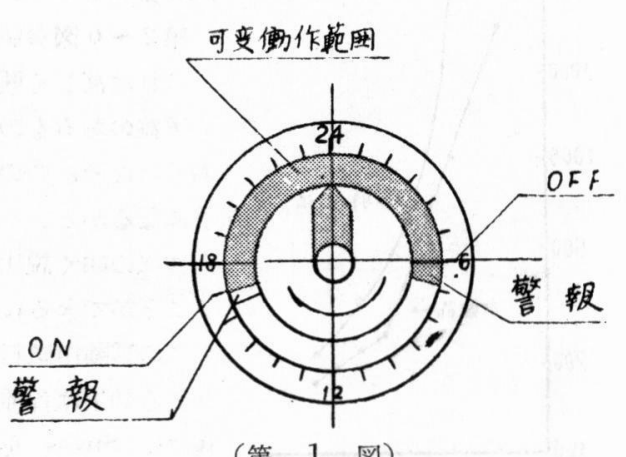

（第 1 図）

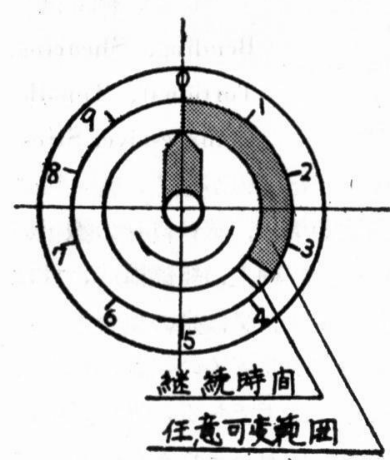

（第 2 殴）
標準タイマ ATM一 $\mathrm{N}$ 型（第 2,3 図参 照)

最も用途の広いタイ マで,一つの操作をあ る特定時間だけ行ろか 又は特定の遅延時間を 要する場合に使用する もので, 目盛は 0 15 sec, $0 \sim 60 \mathrm{~min}, 0 \sim$

$12 \mathrm{hr}$ 等, 任意要求されたものができる. 又動作時限は 0 から最大目盛まで, 自由に可变調整ができて一動作を 終った時, 又は随時自動的に 0 に復帰することができ る.な敃警報等に用ろるために設定時間経過後, 短時間 を継続動作する接点を備えた型式もある.

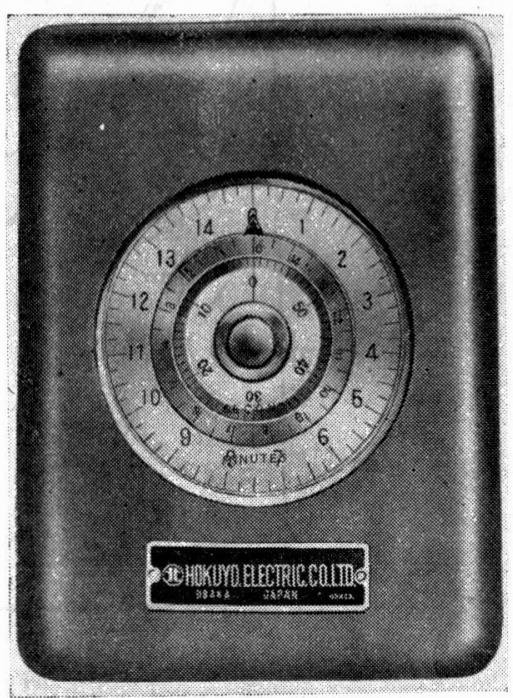

（第 3 図）標準オートタイマ 
用途

自動攪拌嘰, 写真工業, 誘導加熱炉, 染色機器, プレ ス機, 工作機, ソレノイドの自動操作, 蒸絨機, 乾虫機 並びにストップモーションの遅延装置機械のシーケン 起動等.

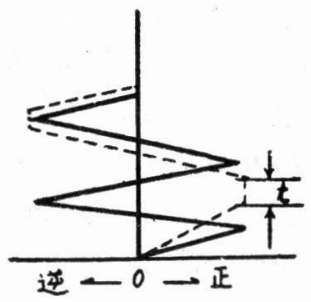

正逆同タイムの\&の 点線は警報等の時間 を插入せるもの (第 4 図)

反覆タイマプログラム

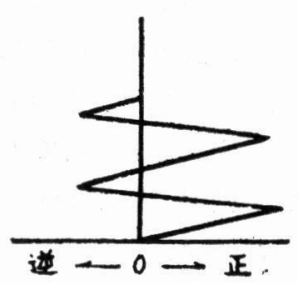

正逆タイマの異なるも (第 5 図) 反覆タイムプログラム
反覆タイマ(第 $4 ， 5$ 参照)

ある特定時限で繰返し正逆転するものか, 又は薬品注 大等で運転停止を繰返す機械の操作を司るもので, ダイ ヤル上を同一时間で往復する ATM- 2 型と，正逆時間 を任意に変えられる $\mathrm{ATM}$ - 3 型と 2 種類がある・との 正逆切返点で警報等を行う・短時限を継続插大する型式 もある. 又いずれも随時自動復帚することができるほか 反覆回数又は動作時間積算数で自動停止することができ る.

用途

染色ポンプ, ジガー, 攪拌機, 洗漀機等の自動正逆運 転とか紡績, 電線, 鋼線工場に拈ける無停台エンドレ ス, 自動運転及び化学工場に㧤いて, 定時限に薬品を注
大する場合等.

ATM-X 型シーケンス オートタイ マ (第 6，7， $8,9,10$ 図参照)

第 9 図の如き長時限及び短時間を多重復継続せるタイ マで, 必要段階はすべて可変調整される構造で, 用途に 応じ特別に設計される.

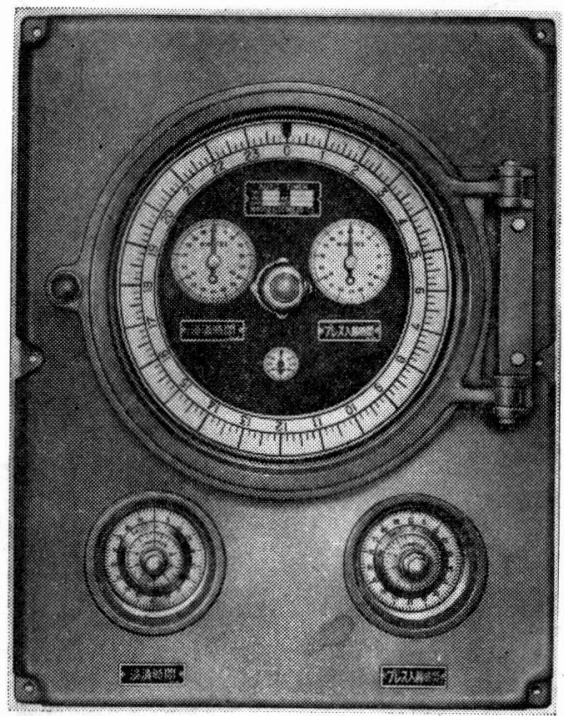

（第6罒） シーケンスタイマ

用 途

連続乾燥機，セルローズ，粉砕機，浸漬機，並びに蒸 絨機等の自動制御, 又は多数一群のモー夕を起動するに 当り作業管理上, 或は電源保護のために, 順々に起動を 要する場合は大型電動機の自動起動等.

ATV 型電子管式タイマ（第 11,12 図参照）

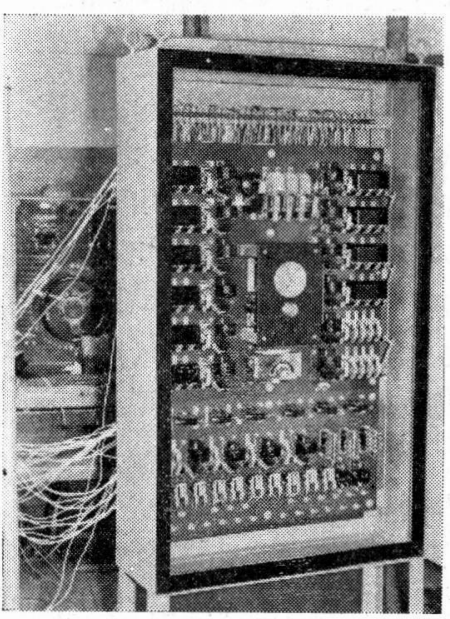

（第 7 図）

連続乾燥機用

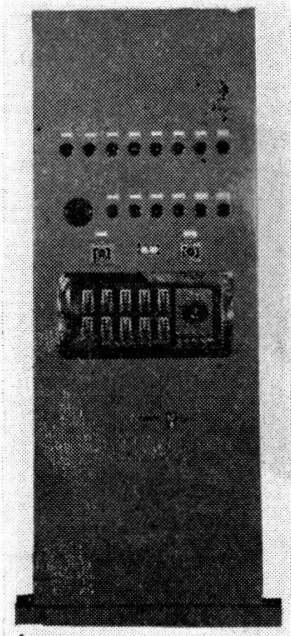

（第 8 図）コンベャ用 シーケンスタイマ

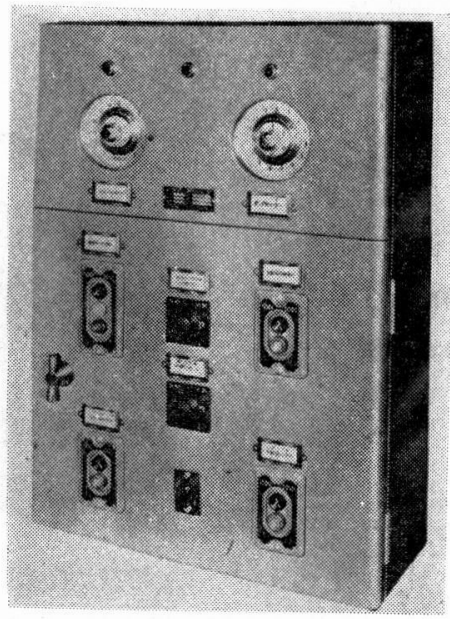

(第 9 図) 蒸䄉機自動制御タイマ 


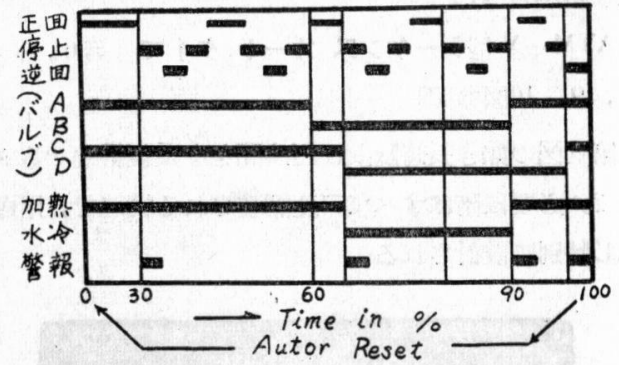

(第 10 汹) シーケンスタイマ動化プログラム

コンデンサと抵抗を組合せた時間特泩を応用し，これ をサイラトロンに導入し時限動作するすので, 正確でし かも比較的短時限の回路に用いられる.

用途

電気熔接機, 工作機, 高周波ミシン, 加熱炉, 写真工 業等

\section{空気ダッシュ ポット 式タイマ}

交流又は直流のソンノ イドに特殊な乾性滑性材 製の空気ダッシュポット （特許）で制動し接点を 開閉するタイマで，タイ ムの調整はポット內に宾 気の流入する孔をネジ調 整し, 復帰は速返りする バルプを備えている本器 は周网温度や振動の影響 を受けることなく，又長 年月使用するも劣化する ことがない.

用途

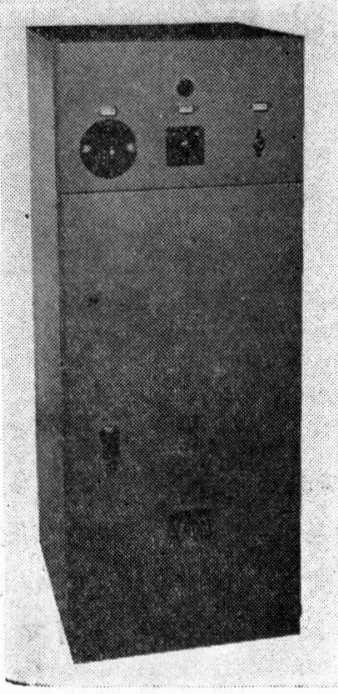

（第 11 図）

ATV 型電気熔接タイマ

機械の自動ブレー キ,モータの自動起 動, ストップモー ション遅延時間等.

\section{紡織及び纎維工場} の実施例

1) 粗紡, 連篠, ピンドラフタ, ギ ルボックスでフィ ード, ストップモ ーションが装置され た機械において篠切

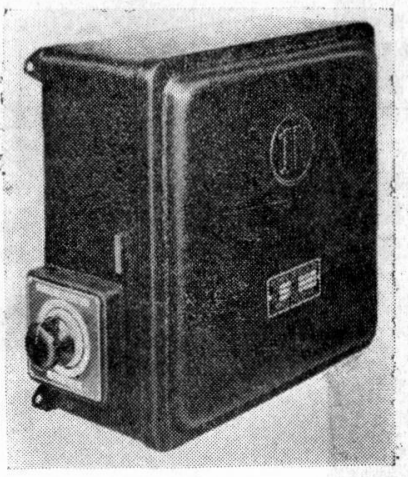

（第 12 闵）

ATV 型高周波ミシン用電子 管タイマ
れした時即時停止せず，信号灯で一応篠切表示をなし10
〜 $15 \sec$ 後即ち切口がパックローラに至る直前になれ ぼ停止するタイマを用いて，停台するまでに篠切れを直 し，ストップモーションによる停台回数を減じ，運転 率の低下を防止する。

\section{2) 粗紡機及び精紡機}

クッションスタータを使用する場合，主として電流 リレで自動操作されるが，既設台で単にクッション部分 のみを追加取付けする場合（特に数個所から寸行運転を する) 予定起動時間で（約 $5 \sim 6 \sec$ 後）クッション装 置を自動的に拢くために，空気式タイマが使用される。 これは油大式に比し,油洩れ污損及ぴ時間の狂いがない。

3 ) 蒸緉穖

毛織工場において緁布を蒸気で一定時間蒸す工程を往 来手動で時詰を睨みながら運転したものを，押釦の一押 で自動的にタイマが働き，パルブを開き，蒸気を通し， 一定時間（0〜10 min 間）持続し次にバルプが切換り， 排気ポンプでヌ一定時間 ( 0 〜 $10 \mathrm{~min}$ 間) 排気をなし, 一 工程終了と同時にペルが数 sec 間鳴って停止復旧する. これは常に一定時間であるから品質が圴一となる.

\section{4) 脱 水 袎}

繊維又は布を遠心分離機で脱水する場合 0 〜 30min 目 盛のタイマを用い, 脱水終了予定時間でペルが鳴り自動 停止すると同時に復旧する・これは含水量圴一の製品と なる

5) 染色ポンプ, 乾煤機等

熱風乾燥機の弁切換え，梳毛トップ染色ポンプ及び綛 染色機等の正逆転等交互に反覆㡖作をなし，との反覆数 又は时間で自動停止をするものにタイマを用い，工数を 省き品質の圴一をする。な拓熱風乾煤機には $0 \sim 15 \mathrm{~min}$, 染色ポンプには $3 \sim 5 \mathrm{~min}$ ，又綛染機には $0 \sim 8 \mathrm{sec}$ と 0〜10 min の復合タイマを使用する。

6) 剪 毛 機

毛織の剪毛機自動及掦装置に括いて，フィーラ又は光 電管で継目を探知して，双を掦下する時限装置に挌いて その時間の進み，遅れをタイマを用いて自動制御し，工 数を省き安全運転をなすこのタイマにはモータ式を用 ろることああるが，主として電子管式を用い 0～1 sec と $0 \sim 5 \mathrm{sec}$ 両様がある.

7) 浸 漬 機

スフ製造工場の浸漬機をタイマを用いて苛性ソーダの 操作及び浸漬時間を自動制御する. 安全運転品質向上, 工数低減となる・これは $24 \mathrm{hr}$ 計 1 個と $0 \sim 30 \mathrm{~min}$ 計 2 個の復合でされる。

8) 粉 砕袎 
スフ製造工場のアルセル粉砕機をタイマを用いて, 正 逆粉砕，加熱，冷却等を自動制御する. 前項同様の効果 を挙け゚る・これは 0〜150 min，0〜100 min の復合でを れる。

9) カード機ケンス満量警報

綿紡のカード機のケンス上り量を一定にするためにタ イマを用い，運転时間でケンス量を算定するタイマを設 定すれば，タイマは一定時間（０３0 min）がたてば約 $30 \mathrm{sec}$ 間ランプを点けペルを鳴らし, 自動的に復率し, 満量警報反覆する.

作業員はベルのたびにカード機一列のケンス交換をす る.これは連篠工程の段取りが艮くなり, 作業管理がよ
くなる・

\section{む す び}

以上列記した如く, 用途により種々のオートタイマ が製造されているが，オートタイマが単独で使用され ることは甚だきれで, 実際には合理化のための対時自動 制御装置の頭脳的役割に使用される場合が多い、䌘社は 自動制御に30年の経験と技術を有して拉り, 前記オート タイマの外, 多種多様の自動制御機器の製造をなしてこ れを綜合駆使して，自動制御方式を実施される相談所と しての協力をあ致しているのである.

\section{$\left(\begin{array}{l}\text { 北 陽 電 気 株 式 会 社 } \\ \text { 大阪市北区梅田新道 日産ビル }\end{array}\right)$}

\section{MS 105 型キマタ式部分整経機}

MS 105 型キマタ式部分整経機は東洋嘰料工業の製作 にかかる優秀機として手織業界に関心をすたれている. 以下大要を紹介する.

\section{1. 本機設計の重点}

a) テンションむらを無くすること.（等テンション 装置)

b）整経による経筋だちを完全に消すこと。

c ) 整経作業は従来のものに比してできる限り自動化 を図り，能率を極度に上昇させること。

d）製織時に性つまりを全然無くして経切れを防止: すること.

e）初心者に親しみやすく取扱い容易なこと。

f ）設備費，人件費の減少を極力図ること.

\section{2. 各種裝置の特長}

\section{a ） 運転装置}

運転は運転棒の操作によりモータ直結部のコンクラッ チを大れる。

なお二段変速クラッチを設けてある. 又ドラム及びヤ ーンビームの回転にも二段変速ができるから如何なる 系質系量のものでも自由に運転することができる・（第 1,3 図)

\section{b) ドラムの始動停止及び逆転}

ドラムの始動は 16 in のVプーリの內側に設けたコン クラッチによって駆動されるので, 自由に緩速始動をす

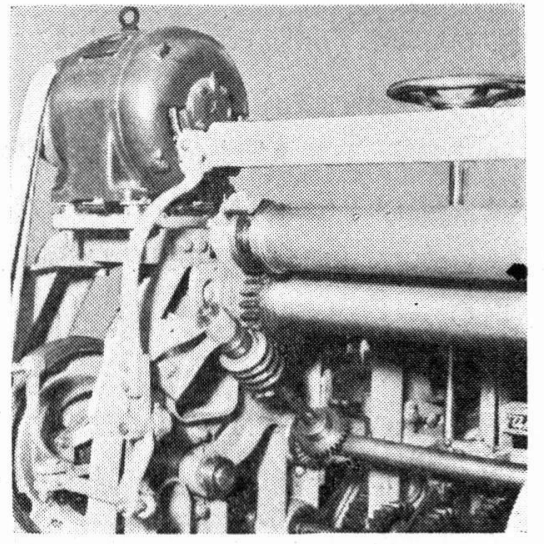

（第 1 図）

ることができるから，始動時における経切れの事故は全 然無く,ドラムの停止は停止ぺタルを踏むことによって 急停止及び惰力停止の両方共行うことができる. 又ヤー ンビームに卷きたる経糸をドラムに卷返すこともでき ろ.

クリールはV型クリール，H型クリールのいずれの使 用にも適している.

c）前筬送り装置

チエン使用のエンドレス装置と10段変速の雪車式によ って連続均等の移動ができる・枕は上下可動の自由式で ある.

な颃従来のラチェット式の送り装置では経切れのため ドラムを逆転すれば, 前筬移動にはドラムの回転角度約 
240 ํ上のギャップがあるのに引換党，乙の装置では約 20 以內で前筬が移動するから優秀な整経ができる・第 2 図)

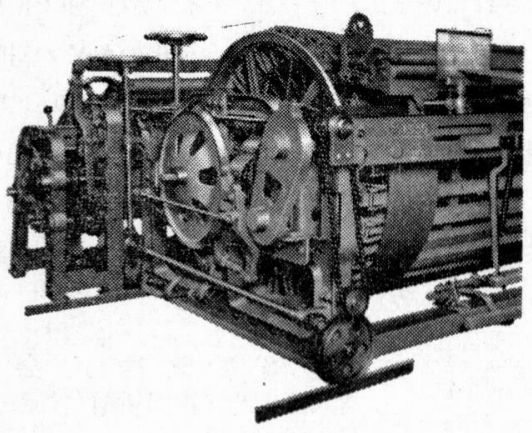

(第 $\quad 2$ 図)

d） ドラム機本体の移動装置

ドラム機の 4, 個の車輪には抒の扔のボールベアリン グを入れてあるので, 巻返機側に設けた 11 in の丸型八 ンドルにより軽く移動ができる・又ヤーンビームに卷 返しの場合のドラム機本体の移動は丸型ハンドルを 1 回 転操作すれば自動的に切換えられる。(第2図)

e) ブレーキ装置

ブレーキの確実と均等を期するために山型ブレーキ ホィールと丸型ハンドルを両側に設けてある・左右両側 連動式になっているのでブレーキの調節は至極便利であ る. (第 2 図)

f) 卷返機

直径 24 in 以上のフレンジ付ヤーン ビームでも使用 できる・又卷終ったャーン ビームは丸型ハンドルで吊 り上げて容易に取外すととができる.（第 1,3 図）

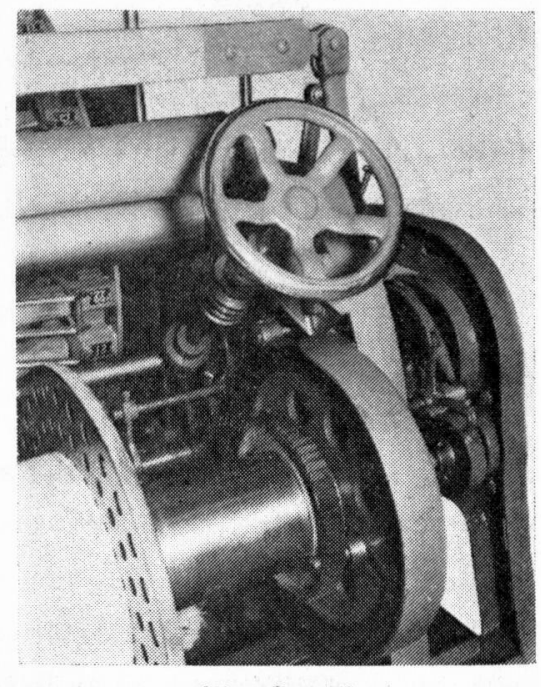

(第 3 図) g) 等テンション ローラ

このローラはヤーン ビームに卷始めと卷終りのテン ションを等しくするため, 自動的に移動するから従来の 如くブレーキハンドルで調節する不便はない。

又手動で上下るできるのでドラムからヤーンビーム へ経系を連結する場合には極めて容易で時間の節約がで きる. (第 3 図)

h) 綾振口ーラ

ローラの一端にカムを設けてある・とれはャーン ビ ームに巻返すとき経糸の配列を調整する. 又ヤーンビ 一ムには経糸が交叉の状態に巻かれる如く設計してある から経系は喰い込むことなく, 整然と卷返され製織時の 眭つまりによる経切れはこれで完全に防止される。【第 1 困)

\section{3. 整経機の諸元}

ドラム円周 $3.5 \mathrm{~m}$

所要馬力 $2 \mathbb{P}$

能 率 1台につき織機15３0台

所要床面積 $2.5 \times 4$ 間

ドラム回転変速 4 段（系流速每 $\min 45 \sim 80 \mathrm{~m}$ )

重 量 $2600 \mathrm{~kg}$

用途毛, 綿, 麻, 絹, ナイロン, サラン, その他各種化学㰇維の整経用

\section{4. 整経機能率試験結果}

某有名工場にて MS 105 型（S）を使用した場合と在 来の某機 (F) を使用した場合の結果を第1表に示す.

ドラム円周は 105 型 (S) $3.5 \mathrm{~m}$ ，旧型 (F) $2.4 \mathrm{~m}$

(1) 整経回数 3 割增しで反数が 2 倍になったにもかか わらず, 時間は $3 \%$ 長いのみ

(2) 整経回数多く, 整経長 2.5 割増しにかかわらず, 時間は 1.6 割短い

(3) 反数 7 割增しにかかわらず時間は短い. 次行に比 較したら整経長 2.5 割増しで回数多いにかかわらず 時間は 3.6 割減

(4) 整経回数 1 割減, 整経長 1.2 割増しにて時間は 2.5 割減

(5) 整経回数 1 割増しにて時間は 5 割短い

\section{試験結果概評}

（1）無地物 6000 本 $2 / 48$ で $13 \mathrm{hr}$ 実働の 整経反数 は 8反のところ16反となった.

（2）製織の場合「畦つまり」がまったく無い。（旧 
（第 1 表）

\begin{tabular}{|c|c|c|c|c|c|c|c|c|c|c|}
\hline 式 & 品 & 番 手 & 筬 & $\begin{array}{l}\mid \text { 総経系本数 } \\
\text { (本) }\end{array}$ & $\begin{array}{l}\text { 染立本数 } \\
\text { (本) }\end{array}$ & $\begin{array}{l}\text { 整経回数 } \\
\text { (回) }\end{array}$ & 整経長 & $\begin{array}{l}\text { 反数 } \\
\text { (反) }\end{array}$ & $\begin{array}{l}\text { 時 間 } \\
(\mathrm{hr})\end{array}$ & 備考 \\
\hline $\mathbf{F}$ & スコッチ & $2 / 16$ & $(12 \times 3) 71 \frac{1}{2}$ & 2574 & 150 & 17 & 57 & 3 & 3.05 & \\
\hline $\mathrm{S}$ & スーパサキソ & $2 / 21$ & $(19 \times 2) 73 \frac{1}{2}$ & 2794 & 128 & 22 & 58 & 6 & 3.10 & \\
\hline $\mathbf{F}$ & スコッチ & $2 / 16$ & $(12 \times 3) 71 \frac{1}{2}$ & 2574 & 150 & 17 & 57 & 3 & 3.25 & \\
\hline $\mathbf{S}$ & " & $2 / 12$ & $(12 \times 2) 71$ & 1704 & 110 & 16 & 55 & 4 & 2.15 & \\
\hline $\mathbf{F}$ & ミルドウーステッド & $2 / 56$ & $(17 \times 4) 71 \frac{1}{4}$ & 4844 & 252 & 20 & 73 & 3 & 5.05 & \\
\hline $\mathbf{S}$ & II & " & $(17.5 \times 4) 701 / 2$ & 4934 & 216 & 23 & 73 & 3 & 4.15 & (2) \\
\hline $\mathbf{F}$ & ミルドウーステッド & $2 / 56$ & $(17 \times 4) 7] 1 / 4$ & 4844 & 180 & 27 & 73 & 3 & 3.20 & \\
\hline $\mathbf{S}$ & " & " & " & 4844 & 180 & 27 & 73 & 5 & 3.05 & (3) \\
\hline $\mathbf{F}$ & ミルドウーステッド & $2 / 56$ & $(17 \times 4) 711 / 4$ & 4844 & 190 & 26 & 73 & 5 & 4.42 & \\
\hline $\mathbf{F}$ & " & " & "I & " & 220 & 22 & 73 & 5 & 5.20 & \\
\hline $\mathbf{F}$ & $\begin{array}{c}\mathrm{DW} \text { ミルド } \\
\text { ウーステッド }\end{array}$ & $2 / 48$ & $(18 \times 6) 74, \frac{1}{2}$ & 8046 & 276 & 30 & 58 & 3 & 5.20 & \\
\hline$S$ & $\begin{aligned} \text { ファンシイ } \\
\text { ウーステッド }\end{aligned}$ & $2 / 52,2 / 64$ & $(15 \times 6) 68$ & 6120 & 228 & 27 & 6.5 & 3 & 3.50 & \\
\hline $\mathbf{F}$ & スコッチオーバ & $2 / 6$ & $(8.5 \times 2) 701 / 2$ & 1198 & 232 & 10 & 53 & 3 & 2 & 5) \\
\hline $\mathbf{S}$ & " & "1 & I & ” & 112 & 11 & 53 & 3 & 1.05 & 5) \\
\hline $\mathbf{F}$ & " & " & " & "I & 120 & 10 & 53 & 6 & 6.50 & \\
\hline
\end{tabular}

型使用の場合 $1 \mathrm{~m}$ 間に1本の経切れがあるとすれ

ば 105 型使用の場合は $1 \mathrm{~m}$ 間に0.5 本の経切れも ない)

\section{5. 特許の諸裝置}

木整経機の特許並びに実用新案（発明者 木全正次）

名は次の通りである。

整経機における無端鎻式移行装置

（特願 昭 28一22722，出願公告洪定 昭 29.12.8） 整経機とビーム機との並列を利用して参返しのテンシ ョン調整装置

（特願 昭 28-22724, 公決 昭 30.2.12) 整経機に拈ける転回ドラム自動停止装置

（特願 昭 28-22726, 公洪 昭30.1.11）
整経機体移動調整装置

（特願 昭 $28-22728$, 公決 昭 30.1 .11 ) 整経機に北けるメー夕転回器

（実願 昭 $28-37059$ ，公決 昭30.2.19） 整経機のドラム回転調整装䈯

（实願 昭 28 - 37060, 公決 昭30.2.19) 整経機に扣ける無端带移行用誘導器

（特願 昭 28-22723，公沈 昭 29.12.8) 整経機に拁けるメ一夕指針逆転装置

（特願 眧 28-22725, 公決 昭30.4.28) 整経機の:無端鎻回転变速装置

（特願 昭 28.22727 , 公決 昭30.1.10) (東洋機料工業株式会社 名占屋行千種入都通 1) 